\title{
Why Did Sudanese End Stage Renal Failure Patients Refuse Renal Transplantation?
}

\author{
Amin S. Banaga ${ }^{*}$, Elaf B. Mohammed2, Rania M. Siddig2, Diana E. Salama², \\ Sara B. Elbashir'2, Mohamed 0. Khojali², Rasha A. Babiker3, Khalifa Elmusharaf, \\ Mamoun M. Homeida ${ }^{5}$ \\ ${ }^{1}$ Department of Medicine \& Nephrology, University of Medical Sciences and Technology, Academy Charity \\ Teaching Hospital, Khartoum, Sudan \\ ${ }^{2}$ Clinical Research Assistants, Department of Nephrology, Academy Charity Teaching Hospital, Khartoum, Sudan \\ ${ }^{3}$ Department of Basic Sciences, Faculty of Medicine, University of Medical Sciences \& Technology, Khartoum, \\ Sudan \\ ${ }^{4}$ Department of Epidemiology \& Public Health Medicine, Royal College of Surgeon in Ireland (RCSI), Dublin, \\ Ireland \\ ${ }^{5}$ Department of Medicine, Faculty of Medicine, University of Medical Sciences \& Technology, Khartoum, Sudan \\ Email: ${ }^{*}$ amin.banaga@gmail.com
}

Received 15 May 2015; accepted 1 June 2015; published 4 June 2015

Copyright (C) 2015 by authors and Scientific Research Publishing Inc.

This work is licensed under the Creative Commons Attribution International License (CC BY).

http://creativecommons.org/licenses/by/4.0/

(c) (i) Open Access

\section{Abstract}

Renal transplantation remains the most effective treatment of End Stage Renal Failure (ESRF). In this cross sectional study we explore the reasons behind refusal of renal transplantation among adults' Sudanese haemodialysis patients. The subjects of the study are ESRF adults' patients on regular haemodialysis treatment in 15 haemdoialysis centres in Khartoum/Sudan. All patients who are on regular haemodialysis were interviewed by questionnaire to explore the reasons of refusal of renal transplantation. A total of $1583 \mathrm{ESRF}$ adults' patients on regular haemodialysis have been participated in the study, $381(24.1 \%)$ patients refused kidney transplantation. The mean age of patients refusing kidney transplantation was (58.5 + 15.1 years); $77.4 \%$ of them were $\geq 50$ years old, $\mathbf{5 9 . 2 \%}$ were males and $\mathbf{8 8 . 1 \%}$ were unemployed, patients older than 50 years old and unemployed are tend to refuse renal transplantation $(P<0.001)$. The main reason of refusal was that the patients refuse to accept kidney from living donors (34.8\%). $17.6 \%$ of patients decline kidney transplantation because of financial reason, $18.1 \%$ of patients refused to do transplantation because of fear of transplant surgery, $15.7 \%$ of patients believe that kidney transplantation is against their religious values, $\mathbf{1 1 . 9 \%}$ of patients refused transplantation because they don't have enough knowledge on renal transplantation, only $0.5 \%$ of patients refuse transplantation because of side effect of immunosuppressive drugs. In conclusion, in this study we found that elderly and unemployed ESRF patients tend to refuse renal transplantation, the most important

\footnotetext{
*Corresponding author.
}

How to cite this paper: Banaga, A.S., Mohammed, E.B., Siddig, R.M., Salama, D.E., Elbashir, S.B., Khojali, M.O., Babiker, R.A., Elmusharaf, K. and Homeida, M.M. (2015) Why Did Sudanese End Stage Renal Failure Patients Refuse Renal Transplantation? Open Journal of Nephrology, 5, 35-39. http://dx.doi.org/10.4236/ojneph.2015.52005 
reason behind refusal of renal transplantation is refusal of accepting kidney donation from living related donors. This reflects the need for development of cadaveric donors program in the Sudan. ESRF patients need education and counseling on renal transplantation.

\section{Keywords}

\section{Sudan, ESRF, Transplantation, Refusal}

\section{Introduction}

Renal transplantation remains the most effective treatment of End Stage Renal Failure (ESRF). Only seven countries in Sub Saharan Africa (SSA) including Sudan have renal transplantation program [1]. Renal transplantation in Sudan is from living donors and no cadaveric donation program is available. The first patient transplanted from a living donor in Sudan was in 1974. Renal transplantation constitutes $28.4 \%$ of total Renal Replacement Therapy (RRT) in Sudan [2] [3].

Known the fact that renal transplantation improves the quality of life of ESRF patients, still some patients refuse renal transplantation. A previous study conducted in Sudan explored the barriers to kidney transplantation among 462 ESRF patients who are on maintenance haemodialysis [4]. In this study, we focused on ESRF patients who refused renal transplantation exploring in depth the main reasons behind their refusal and the determinants of their decision.

\section{Materials and Methods}

This study is a cross sectional hospital based descriptive study. All patients on regular haemodialysis in 15 hemodialysis centers in Khartoum-Sudan were approached to participate in the study in the period from 1/11/2014 to 1/12/2014. Out of 1602 patients a total of 1583 ESRF adults' patients on regular haemodialysis participated in the study with response rate of $98.8 \%$. A questionnaire was used to collect the personal data (age, gender, occupation, duration of dialysis), and for those who refuse renal transplantation we explored the reasons for non acceptance of transplantation. We excluded haemodialysis patients who are less than 18 years old and haemodialysis unit where located in rural area of Khartoum State. Statistical analysis was performed using SPSS 21 software package (SPSS Inc, Chicago, IL, USA); results were presented in number, percent, mean and standard deviation. Chi-square and student $\mathrm{t}$ tests have been used to test the statistical significance and $\mathrm{P}$ values $<0.05$ were considered significant. Ethical clearance was obtained from the ethics and research committees of the ministry of health/Sudan. Permission for the study was obtained from directors of the dialysis units. An informed consent was obtained from each patient participated in the study.

\section{Results}

A total of 1583 ESRF adults' patients on regular haemodialysis participated in the study, 381 (24.1\%) patients refused kidney transplantation. The mean age \pm (SD) of patients refusing kidney transplantation was $58.5 \pm 15.1$ years , $77.4 \%$ of them were $\geq 50$ years old, $59.2 \%$ were males and $88.1 \%$ were unemployed (Table 1 ). In this study we found that patients who are older than 50 years old and unemployed tend to refuse renal transplantation $(\mathrm{P}<0.0001)$ (Table 1).

The reasons of refusal of kidney transplantation are shown on Table 2. The main reason was that patients do not want to accept kidney from life related donors (34.8\%). Other mentioned reasons were financial reason (17.6\%), fear of transplant surgery (18.1\%), believes that kidney transplantation is against their religious values (15.7\%), they do not have enough knowledge on renal transplantation (13.4\%), fear of the side effects of immunosuppressive drugs (0.5\%).

\section{Discussion}

In this study, we found that elderly patients ( $\geq 50$ years) tend to refuse renal transplantation more than young 
Table 1. Characteristic of patients refuse kidney transplantation.

\begin{tabular}{|c|c|c|c|}
\hline & Accept Transplantation & Refuse transplantation & $P$ value \\
\hline Age $^{1}$ & $46.18 \pm 15.13$ years & $58.5 \pm 15.1$ years & $<0.0001$ \\
\hline $\begin{array}{l}\geq 50 \text { years old }{ }^{2} \\
<50 \text { years old }\end{array}$ & $\begin{array}{l}530(44.1 \%) \\
672(55.9 \%)\end{array}$ & $\begin{array}{l}295(77.4 \%) \\
86(22.6 \%)\end{array}$ & $<0.0001$ \\
\hline Occupation $^{2}$ & $\begin{array}{l}\text { Employed 331(27.5\%) } \\
\text { Unemployed } 871 \text { (72.5\%) }\end{array}$ & $\begin{array}{l}\text { Employed } 44 \text { (11.5\%) } \\
\text { Unemployed } 337 \text { (88.5\%) }\end{array}$ & $<0.0001$ \\
\hline Gender $^{2}$ & $\begin{array}{c}\text { Male } 775(64.5 \%) \\
\text { Female } 427 \text { (35.5\%) }\end{array}$ & $\begin{array}{c}\text { Male } 229(60.1 \%) \\
\text { Female } 152(39.9 \%)\end{array}$ & 0.12 \\
\hline Duration of dialysis ${ }^{1}$ & $4.37 \pm 3.9$ years & $4.41 \pm 4.96$ years & 0.89 \\
\hline
\end{tabular}

${ }^{1}$ Mean \pm SD. ${ }^{2}$ Number (percentage).

Table 2. Reasons behind refusal of renal transplantation.

\begin{tabular}{cc}
\hline Reasons behind refusal of renal transplantation & Frequency (\%) \\
\hline Financial & $67(17.6 \%)$ \\
Fear of renal transplant surgery & $69(18.1 \%)$ \\
Refuse to accept kidney from living donors & $132(34.8 \%)$ \\
Religious & $60(15.7 \%)$ \\
Lack of knowledge about renal transplantation & $51(13.4 \%)$ \\
Immunosuppressive treatments side effects & $2(0.5 \%)$ \\
\hline
\end{tabular}

patients. As has been shown before in previous study, age was a factor in refusal of renal transplantation [5]. Patients who are employed tend to accept renal transplantation. This might reflect that frequent visits to hospital to receive hemodialysis affect the working life of our patients. However, we found no significant difference regarding gender or duration of dialysis.

Almost one in four ESRF patients refused to perform renal transplantation. Several studies pointed out that renal transplantation is associated with better quality of life when it compare with dialysis [6]-[8]. However, there were many studies reported increase number of patients who are refusing renal transplantation. In Morocco a study reported that $37.4 \%$ of ESRF patients were wouldn't like to go for renal transplantation [9]. In Slovenia, $13.7 \%$ of ESRF patients refused renal transplantation [10].

One in three patients who refused to go for renal transplantation stated that they do not want to accept kidney from living related donor. This raises the importance of establishing a cadaveric donor program in Sudan. In SSA, only South Africa has a cadaveric donor program [1]. Published data clearly reported that living kidney donation from healthy persons is associated with minimal perioperative risk [11]. A review of medical literature on living kidney donation found that unilateral nephrectomy is not harmful to healthy persons [12]. Increase awareness of ESRF patients and potential kidney donors about the living kidney donation is essential to increase the number of transplanted patients.

Financial constrains was one of the causes for refusal of renal transplantation despite that renal transplantation surgery in Sudan is free and the immunosuppressive treatments are distributed free for patients. However, patients and donors still need to pay for the necessary investigations and work-up pre transplant. On the other hand, some patients wish to do renal transplantation outside Sudan. The reason for that is the long waiting list. In previous study conducted in Sudan about attitude of patients toward renal transplantation reported that $24.2 \%$ of ESRF patients could not proceed to renal transplantation because of financial problems [4]. The same results were obtained from developed countries where reported that low socioeconomic status and lack of medical insurance was associated with failure of or delay of renal transplantation [13].

One in five of patients who refused renal transplantation were due to fear from the transplant surgery. There is a need to raise awareness about the risk of transplant surgeries. Transplanted patients have long term lower mortality risk in comparison with dialysis patients [14]. The survival rate after one year of transplantation is 
about $95 \%$ and around $90 \%$ on five years' post transplantation [15]. The quality of life is markedly improved with transplantation [16].

Among those who refused renal transplantation, $15.7 \%$ of patients reject transplantation because of religious reasons believing that Islam is against renal transplantation. Islam does not prohibit transplantation. In 1988, the Islamic Jurisprudence Assembly Council in Saudi Arabia approved cadaveric and live kidney donations [17]. The same decision about kidney donation has been approved in Iran and Egypt [18]. Despite that, some patients still refuse transplantation based on religious values in Muslims countries. One third of ESRF patient in Morocco refused transplantation on the belief that Islam is against it [9]. In a study conducted in Saudi Arabia, 26.2\% believes that Islam is against renal transplantation [19]. So an increasing awareness is needed from Muslims' scholars and Islamic institutions to promote renal transplantation.

In the current study, $13.4 \%$ of those who refused transplantation stated that they have no enough information about renal transplantation. This reflects the poor counseling on renal transplantation, which should be carried out by physicians and following nephrologists. Several studies pointed out the attitude of health worker toward renal transplantation. In one study, $49 \%$ of physicians they did not agree with live kidney donation and $53 \%$ of them didn't have enough information on renal transplantation [20]. Other study, conducted in Tunisia, reported that $41 \%$ of physicians refused organ transplantation [21]. In previous study in Sudan among haemodialysis patients, 31.6\% of patient reported that they haven’t been counseled for renal transplantation [4]. Education of health workers about renal transplantation might play an important role in increasing the acceptance rate of kidney transplant among ESRF patients.

In the current study, we reported that a minority of patient $(<1 \%)$ refused transplantation because they fear the side effect of immunosuppressive medications. In contrast, other study reported that side effects of immunosuppressive medications are a major reason behind refusal of renal transplantation among ESRF patients [5].

There was limitation in our study, we focused only in patients who refuse renal transplantation however more researches are needed to explore the barriers toward renal transplantation among patients who accept but couldn't perform renal transplantation, in other hand a decision of refusal of renal transplantation may be affected by the cause of the original kidney disease and definitely more researches are needed to explore such association.

\section{Conclusion}

In conclusion, in this study, we found that elderly and unemployed ESRF patients tend to refuse renal transplantation. The most important reason behind refusal of renal transplantation is refusal of accepting kidney donation from living related donors. This reflects the need to develop cadaveric donors program in Sudan. ESRF patients need education and counseling on renal transplantation.

\section{References}

[1] Naicker, S. (2013) End-Stage Renal Disease in Sub-Saharan Africa. Kidney International Supplements, 3, $161-163$.

[2] Suliman, S.M., Beliela, M.H. and Hamza, H. (1995) Dialysis and Transplantation in Sudan. Saudi Journal of Kidney Diseases and Transplantation: An Official Publication of the Saudi Center for Organ Transplantation, Saudi Arabia, 6, 312-314.

[3] Elamin, S., Obeid, W. and Abu-Aisha, H. (2010) Renal Replacement Therapy in Sudan, 2009. Arab Journal of Nephrology and Transplantation, 3, 31-36. http://dx.doi.org/10.4314/ajnt.v3i2.58903

[4] Abdelwahab, H.H., Shigidi, M.M.T., Ibrahim, L.S. and El-Tohami, A. (2013) Barriers to Kidney Transplantation among Adult Sudanese Patients on Maintenance Hemodialysis in Dialysis Units in Khartoum State. Saudi Journal of Kidney Diseases and Transplantation, 24, 1044-1049. http://dx.doi.org/10.4103/1319-2442.118093

[5] Nizič-Kos, T., Ponikvar, A. and Buturović-Ponikvar, J. (2013) Reasons for Refusing Kidney Transplantation among Chronic Dialysis Patients. Therapeutic Apheresis and Dialysis, 17, 419-424. http://dx.doi.org/10.1111/1744-9987.12090

[6] Maglakelidze, N., Pantsulaia, T., Tchokhonelidze, I., Managadze, L. and Chkhotua, A. (2011) Assessment of HealthRelated Quality of Life in Renal Transplant Recipients and Dialysis Patients. Transplantation Proceedings, 43, 376379. http://dx.doi.org/10.1016/j.transproceed.2010.12.015

[7] Chkhotua, A., Pantsulaia, T. and Managadze, L. (2011) The Quality of Life Analysis in Renal Transplant Recipients and Dialysis Patients. Georgian Medical News, 11, 10-17. 
[8] Balaska, A., Moustafellos, P., Gourgiotis, S., Pistolas, D., Hadjiyannakis, E., Vougas, V. and Drakopoulos, S. (2006) Changes in Health-Related Quality of Life in Greek Adult Patients 1 Year after Successful Renal Transplantation. Experimental and Clinical Transplantation: Official Journal of the Middle East Society for Organ Transplantation, 4, 521-524.

[9] Kabbali, N., Mikou, S., El Bardai, G., Tazi, N., Ezziani, M., Batta, F., Arrayhani, M. and Houssaini, T. (2014) Attitude of Hemodialysis Patients toward Renal Transplantation: A Moroccan Interregional Survey. Transplantation Proceedings, 46, 1328-1331. http://dx.doi.org/10.1016/j.transproceed.2014.03.008

[10] Buturović-Ponikvar, J., Gubenšek, J., Arnol, M., Bren, A., Kandus, A. and Ponikvar, R. (2011) Dialysis Patients Refusing Kidney Transplantation: Data from the Slovenian Renal Replacement Therapy Registry. Therapeutic Apheresis and Dialysis, 15, 245-249. http://dx.doi.org/10.1111/j.1744-9987.2011.00945.X

[11] Weitz, J., Koch, M., Mehrabi, A., Schemmer, P., Zeier, M., Beimler, J., Büchler, M. and Schmidt, J. (2006) LivingDonor Kidney Transplantation: Risks of the Donor-Benefits of the Recipient. Clinical Transplantation, 20, 13-16. http://dx.doi.org/10.1111/j.1399-0012.2006.00595.x

[12] Tarantino, A. (2000) Why Should We Implement Living Donation in Renal Transplantation? Clinical Nephrology, 53, 55-63.

[13] Schold, J.D., Gregg, J.A., Harman, J.S., Hall, A.G., Patton, P.R. and Meier-Kriesche, H.-U. (2011) Barriers to Evaluation and Wait Listing for Kidney Transplantation. Clinical Journal of the American Society of Nephrology, 6, 17601767. http://dx.doi.org/10.2215/CJN.08620910

[14] Wolfe, R.A., Ashby, V.B., Milford, E.L., Ojo, A.O., Ettenger, R.E., Agodoa, L.Y., Held, P.J. and Port, F.K. (1999) Comparison of Mortality in All Patients on Dialysis, Patients on Dialysis Awaiting Transplantation, and Recipients of a First Cadaveric Transplant. New England Journal of Medicine, 341, 1725-1730. http://dx.doi.org/10.1056/NEJM199912023412303

[15] Briggs, J.D. (2001) Causes of Death after Renal Transplantation. Nephrology Dialysis Transplantation, 16, $1545-1549$. http://dx.doi.org/10.1093/ndt/16.8.1545

[16] Evans, R.W., Manninen, D.L., Garrison Jr., L.P., Hart, L.G., Blagg, C.R., Gutman, R.A., Hull, A.R. and Lowrie, E.G. (1985) The Quality of Life of Patients with End-Stage Renal Disease. New England Journal of Medicine, 312, 553-559. http://dx.doi.org/10.1056/NEJM198502283120905

[17] Golmakani, M.M., Niknam, M.H. and Hedayat, K.M. (2005) Transplantation Ethics from the Islamic Point of View. Medical Science Monitor, 11, RA105-RA109.

[18] Einollahi, B. (2008) Cadaveric Kidney Transplantation in Iran: Behind the Middle Eastern Countries? Iranian Journal of Kidney Diseases, 2, 55-56.

[19] Mohamed, E. and Guella, A. (2013) Public Awareness Survey about Organ Donation and Transplantation. Transplantation Proceedings, 45, 3469-3471. http://dx.doi.org/10.1016/j.transproceed.2013.08.095

[20] Nadoushan, M.S., Heshmati, B.N., Pirsaraee, A.S., Nodoushan, I.S., Nadoushan, R.J. and Yazdi, F. (2014) Knowledge and Attitude of Iranian Physicians towards Organ and Tissue Donation. International Journal of Organ Transplantation Medicine, 5, 66-70.

[21] Tebourski, F., Jaouadi, N., Ben, A.D., Benamar-Elgaaied, A. and Ayed, M. (2003) Attitude of Health Personnel to Organ Donation and Transplantation. La Tunisie Medicale, 81, 482-487. 